\title{
LocAL LANDSCAPES, GLOBAL CINEMASCAPES, AND THE NEW GALICIAN DOCUMENTARY
}

\author{
Samuel Amago \\ The University of North Carolina at Chapel Hill
}

\begin{abstract}
Aвstract: This essay analyzes recent experimental documentaries by Lois Patiño and Xurxo González (aka Xurxo Chirro) within the context of the Novo Cinema Galego, its digital modes of production, its geographical aesthetics, and the ways in which it visualizes ever-evolving notions of Galician identity and point of view. While these directors' films problematize formal barriers, boundaries, and distinctions, they also draw special attention to national and regional geographies, cultures, identities, languages, in order to make the Galician Worldview visible onscreen.

Keywords: Space; place; documentary; Novo Cinema Galego; experimental film; digital cinema.
\end{abstract}

Paisaxes locais, Cinemascapes Globais e o novo documental galego

Resumo: Este ensaio analiza os recentes documentais experimentais de Lois Patiño e Xurxo González (tamén coñecido como Xurxo Chirro) dentro do contexto do Novo Cinema Galego, os seus modos dixitais de produción, a súa estética xeográfica e as maneiras nas que visualiza as nocións, en evolución constante, de identidade e punto de vista galegos. Os filmes destes directores, ao tempo que problematizan barreiras, divisións e diferenzas formais, tamén chaman a atención sobre xeografías nacionais e rexionais, culturas, identidades e linguas, a fin de faceren visíbel a cosmovisión galega na pantalla.

Palavras chave: espazo; lugar; documental; Novo Cinema Galego; filme experimental; cinema dixital.

Un importante froito destas intencións creativas é que fixo pensar na natureza das imaxes, xa non só na Galiza e no estado español, senón no mundo enteiro.

Bragaña et al. (2015) 
Sabemos sin embargo que el cine es un hijo bastardo, su madre no fue la literatura sino las pobres ferias populares; su padre fue el desarrollo tecnológico, no el arte.

Jesús DíAz (1980: 474)

In a 2014 essay published in Cultura Galega, Inés Vázquez noted that in the Galician cultural context new technologies have allowed «que calquera persoa poida construír un discurso propio, facer unha película ou unha cámara barata e o difundir, isto marca unha diferenza moi grande con outros tempos» (Cultura galega 20I4: n.p.). Even at a time when documentary film faces challenges to «legitimarse como una práctica industrial» (Cerdán 2009: 70), digitalization, self-production and new online channels of distribution and exhibition have increased access across the board, creating «microaudiences» for audiovisual content produced through the hybridization of genres and formats (Gallego and Martínez 2012: 36). Indeed, the same technologies and practices that have made the production of alternative documentary film possible-outside of the industrial system of production, as Cerdán describes it—with cinematic creativity on the production side have allowed the making and distribution of this kind of work to become cheaper and more personal (Cerdán 2009: 73). In a useful essay on how the Internet is transforming audiences and storytelling schemes on the Iberian Peninsula, María Gallego and Isabel Martínez outline how digital modes of production, distribution, exhibition and reception have functioned to accelerate the hybridization and mixing of audiovisual strategies that have always been present in documentary film (2013: 2737). What is perhaps novel about the last fifty years of development of the form is that at the same time that documentary has borrowed from fiction film, fiction film has increasingly borrowed from the aesthetics of documentary and found-footage filmmaking. ${ }^{1}$

- Many of the theoretical texts that emerged in the I970s and I980s in the Americas emphasized the fundamental difference between the fiction film favored and exported by first world colonial powers and the documentary modes that made Latin America visible to the world. Julio García Espinosa noted in 1975: «Pudiéramos decir, que hace ya más de quince años una imagen recorre el mundo. Esa imagen es nuestra propia imagen. No es una imagen de ficción. Es la imagen del cine documental y noticioso de nuestro llamado Tercer Mundo» (I975: 464).

Abriu, 7 (2018): 81-99

ISSN: $2014-8526$, e-ISSN: $2014-8534$ 
In terms of distribution and reception, new and ongoing rural film festivals such as the Festival de Cans, the Festival Internacional de Cinema Rural Carlos Velo (FICCVelo), Cinema Palleiriso, and other experimental outlets, such as the A Coruña-based (S8) Mostra de Cine Periférico and Play-Doc, which takes place in Tui, have contributed to growing popular interest in locally produced films of varying lengths, fiction and nonfiction, produced in Galicia by Galicians. ${ }^{2}$ In professional terms, the festival model represents opportunities for filmmakers to make crucial connections: «a los festivals acuden programadores de otros festivales [...] y otros agentes del sector, directores, productores independientes, críticos, programadores de televisión, distribuidores... Funcionan, paralelamente, como un gran bazar» (Ambrós 2009: 229). And in terms of spectatorship, emerging modes of digital film production and reception, reduced production costs, and new means of exhibition have contributed to the formation of geographically dispersed communities of viewers who are able to access what might otherwise be considered «invisible» forms of cinema. The traditional and largely urban international film festivals that have always sustained independent, national, and regional cinemas (nonfiction and fiction) have been supplemented and in some cases replaced by these more innovative platforms, such as the Galician rural cinema festivals mentioned above, alongside new digital venues such as the Festival Europeo de Cine Invisible (an online film festival organized by Filmotech), mubi.com, Netflix, Vimeo, Amazon Prime, and others. In Gómez Viñas's estimation, «the internet reigns supreme as the ideal channel for diffusion and exchange» within and outside Galicia (Gómez Viñas 20I4: I54).

But reduced state and private funding for motion picture making has impacted aesthetics, narrative scope, production and exhibition. As Iván Villarmea Álvarez notes, «el impacto de la reciente crisis económica ha limitado notablemente las posibilidades de crecimiento de esta industria llegando a amenazar su continuidad» (2015: 202). And more recently, Colmeiro has written that «one of the indirect effects of the crisis in Spain was the dismantling of cultural infrastructure» (2017: I76); as post-crisis economic realities have shut down some cultural and economic opportunities for film production, digital modes have filled the void. For Marta Pérez Pereiro, 2008 marks an «ano

${ }^{2}$ Fernando Redondo Neira (20I6) has analyzed with greater detail how film festivals have broadened the visibility of the NCG.

Abriu, 7 (2018): 8I-99

ISSN: 2014-8526, e-ISSN: 2014-8534 
de inicio da crise que, paradoxalmente, se constitúe como un momento significativamente positivo, cun aumento substancial da produción comercial e a notable presenza doutro tipo de filmes en festivais» (2014-2015: 79).

Since 2010, Galician cinema has risen from the ashes of economic crisis, exploiting an array of new ways of doing movies. This process has been proportionately small, discontinuous, and elaborated from the periphery (Pérez Pereiro 20I4-2015: 79). Nonetheless, Villarmea (2015: 202-03) and Colmeiro (2017: 174-77) describe how a diverse group of men and women have used crowdsourcing, digital and small-scale production modes, to build a Novo Cinema Galego (NCG) that has flourished at the margins of the peninsular mainstream. Gómez Viñas observes that technological advances have allowed for the development of a more «autonomous and decentralized production» model through which «studios and large production companies have lost their hegemonic position» (2014: 153), and Xurxo González and Fernando Redondo Neira have outlined how the NCG has been shaped by the financial exigencies of «low-cost» filmmaking (20I4). Peque Varela, Xurxo Chirro, Eloy Enciso, Lois Patiño, Ángel Santos, Lara Bacelo, Marcos Nine, Pela del Álamo, Pablo Cayuela, Xan Gómez Viñas, Sonia and Miriam Albert Sobrino, Susana Rei, Xacio Baño, Sandra Sánchez, Xacio Baño, Alberte Pagán, Sonia Méndez and Oliver Laxe are some of the people who have made idiosyncratic, critically acclaimed films that in turn have drawn new attention to Galician spaces, places, culture and language in a postnational, deterritorialized world. To this end, Villarmea describes how the Novo Cinema Galego has tended towards nonfiction filmmaking using digital production as its principal approach «y la autoproducción como sistema económico» (2015: 202).

At the same time that economic realities continue to impact production, on the reception side, Roberto Cueto has traced the evolution of a «third public» (2008: 10) that has come into being in the digital era, and which has coalesced around films that would otherwise remain unseen. Existing somewhere between the popular audience and a more elite cinephile public, Cueto's «third public» has taken advantage of novel modes of distribution and reception in order to access and experience "cine alternativo o "diferente"» (2008: I0). Cueto asserts that what we are seeing is not «invisibility», but rather «un desplazamiento de la visibilidad a otros espacios y hábitos de consumo» (2008: 10); Villarmea calls this «una red digital descentralizada» (2016: 202-3).

Gallego and Martínez (2012: 29) argue, alongside Cueto, that rather than the death of cinema we are seeing the demise of old ways of thinking about it. 
Digitalization of documentary film has also led to a convergence of museums, movie houses and TV (Cerdán and Weinrichter 2008). In his prologue to Doc 2I: Panorama del reciente cine documental en España, Román Gubern remarks that documentary film in Spain may be in an «estado de ebullición» (2009: 9), producing a wide array of quality productions that have been recognized by specialists and, increasingly, a public that tends to eschew the form in favor of a more commercial form of fiction film. Gubern describes it as a «pérdida de legitimación del documental como práctica industrial, asociada a su falta de legitimación en el imaginario espectatorial dominante» (2009: II). He suggests that the polymorphous landscape of Spanish documentary film configures an imaginary territory whose frontiers are increasingly porous and imprecise (2009: 9).

This essay examines how two Galician filmmakers-Xurxo González (AKA Xurxo Chirro) and Lois Patiño-have engaged in the tradition of innovation and rupture that has always shaped documentary film, and analyzes how they deploy experimental forms of production as a way to reterritorialize a historically marginalized Galician cinema. Building on some of the pioneering work authored by Iván Villarmea Álvarez (20I5), José Colmeiro (20I7), and others, the following pages explore how these two filmmakers associated with the Novo Cinema Galego have sought out new production models, aesthetic approaches, and a robust online activity in order to promote their work and the work of other Galician directors. As Colmeiro notes in his chapter on the Novo Cinema Galego, the peripheral status of the Galician cinema culture is not only understood as a geolocation-a locale existing somewhere at the margins of Spanish national cinemas and Iberian national space-but rather as «a conceptual, ideological, and aesthetic positioning» (20I7: I70) whereby Galician filmmakers have attempted to carve out, burrow below, or otherwise exist outside commercial and cultural mainstreams. ${ }^{3}$ The directors associated

3 Although the Novo Cinema Galego is comprised of a diverse group of filmmakers, they tend to share some of these characteristics: «cinephilia, small crews, the democratisation of technology, self-management, risk, experimentation, improvisation, process, metalanguage, referentiality, landscape, pantheism, irony, humour» (Naughten, quoted in Colmeiro 2017: 179). Colmeiro notes that, in some ways, the NCG borrows from earlier European auteurist paradigms of filmmaking (2017: 18I). Villarmea argues that the relative success of the NCG lies in the skillful way in which its key filmmakers process «lo transnacional a través del filtro de lo local» (2015: 204).

Abriu, 7 (2018): 8I-99

ISSN: 20I4-8526, e-ISSN: 20I4-8534 
with the NCG do not necessarily share an aesthetic, but they do share a propensity for transnationalism and they speak, if not to Galicia, «desde Galicia» (Villarmea 2015: 203).

One of the paradoxes of the Novo Cinema Galego is that, while its peripheral location makes it somewhat difficult to track down, once you have engaged with its practitioners access becomes much easier. In other words, the periphery is difficult to see from the center, but once you get there, new networks of activity, new interpenetrating rhizomes of concepts and audiovisual aesthetics can be detected and explored. An anecdote: commissioned by José Colmeiro to write this essay on Galician documentary filmmaking in the global era, I was initially unable to access new primary sources through the usual channels. Having cultivated a close relationship with the librarians at my university's otherwise expansive Media Resource Center, I was able to acquire and view a handful of titles, such as Eloy Enciso's Arraianos (2013). And in 2010 I was able to work with Zeitun Films to organize a public screening of Oliver Laxe's award-winning Todos vós sodes capitáns (2010; it won the FIPRESCI award at Cannes) at Chapel Hill's Varsity Theatre. But peripheral circuits of distribution are not immediately visible or accessible to the institutional academic, and even well-funded research libraries cannot always facilitate access to materials. (I suspect that, even had I been able to travel to Galicia this year to do research, I would not necessarily have had more success on my own.) Earlier work on Iberian documentary had brought me into contact with Zeitun Films, whose close collaboration with Oliver Laxe has had a visible impact on promoting Galician documentary internationally, with some noteworthy results (Amago 2017), and the invitation from Colmeiro for the present essay provided an opportunity to explore the Galician case more deeply.

But having promised an article on directors such as Oliver Laxe, Xurxo Chirro, Lois Patiño, and Eloy Enciso, my next task was to actually see their films. Amazon in Spain, the U.S., or the Americas was unhelpful. Production companies and cultural organizations were difficult to track down. But a Google search of Xurxo Chirro brought my attention to his Twitter account. A hopeful personal message was promptly answered and the director sent links and passwords to the Vimeo feeds of his recent filmography, including Vikingland (2011), a movie best described as a «documentary border film» (Colmeiro 20I7: 202), or «documento de la emigración» (Villarmea 2015: 210), and which Colmeiro has very appreciatively described as perhaps the emblematic work of the NCG. 
Chirro is one of several Galician filmmakers associated with the online network supporting the Novo Cinema Galego. Colmeiro explains that the filmmaker has been «partially responsible for the new visibility of peripheral Galician cinema, in Galicia and abroad, at a time when paradoxically the general economic and political conditions might appear as less than ideal» (2017: I74). The Novo Cinema Galego website contains a manifesto of sorts, which stipulates that its associated filmmakers engage in «modelos de produción que difiren dos parámetros industriais», deploying «linguaxes anovadoras que ponderan a experimentación», and, with a flourish perhaps more difficult to gauge critically, that their work contain or aspire to a «valor máis alá do feito puramente fílmico, que axuda a desenvolver e a potenciar este tipo de cinema na Galiza» (Bragaña et al. 20I5).4

In my earlier essay described above, I commented on how Zeitun Films carefully curates global scholarly and commercial engagements with their film products, and I considered critically how a film shot in North Africa with an international crew in Arabic and French might be (and should be) considered quintessentially Galician. The thesis of that essay posited that the reduced economies of scale that characterize (and that likely will always characterize) contemporary Iberian documentary give the deceiving impression that this is a small world, but when you are talking about "pequeno cinema», it is just that question of scale that makes access to global audiovisual circuits all the more crucial. In their book on the cinema of small nations, Hjort and Petrie elaborate how the interrelated forces of globalization and internationalization have often been felt especially intensely in these smaller kinds of cultural contexts, since «small nations by definition have very limited domestic markets for all locally produced goods and services-including culture-and so have been forced by the neo-liberal economic and political pressures of globalization into a greater dependency on external markets» (2007: 15). ${ }^{5}$ At the same time, these

4 Colmeiro notes that «although they do not constitute a strictly unified movement», the artists associated with the Novo Cinema Galego «have followed similar paths of experimentation on the margins of the commercial industry, consciously aware of their peripheral position and determined to have their visions projected on the global screen» (2017: I78).

5 Pérez Pereiro (20I4-20I5) and Pérez Pereiro and Redondo Neira (20I3) also describe Galician cinema using the conceptual model established by Mette Hjort and Duncan Petrie (20I7).

Abriu, 7 (2018): 8I-99

ISSN: 20I4-8526, e-ISSN: 20I4-8534 
same nations «have emerged out of twentieth-century processes of decolonization and liberation struggles [with] a strong vested interest in nation-building and the maintenance of a strong sense of national identity relevant both internally and externally to the nation» (2007: 15). This is especially the case in Galicia, which provides an ideal location for exploring «conflicting trends of globalization and identity» (Hooper and Puga Moruxa 20II: I), since it possesses what amounts to a «minority cinema within a minority national film industry» (Colmeiro 20I1: 215). ${ }^{6}$ Pérez Pereiro describes how Galician cinema exists within a double system of domination: «dunha banda, o do cinema hexemónico, baseado nos estándares da industria americana; doutra, o sistema audiovisual español, que condiciona os fluxos de imaxes e o seu estatuto» (2014-2015: 82). And as Villarmea elaborates, Galician documentary film always deals with the theme of Galician national identity «desde una posición conscientemente periférica que tiene mucho de transnacional, puesto que huyen del centro para instalarse en los márgenes, en las fronteras, ya sean genéricas o territoriales» (2015: 214).

The artists and producers associated with the Novo Cine Galego have achieved a noteworthy degree of success in branding their avant-garde filmmaking as part of a Galician New Wave. In what remains of this essay, I will survey how Galician documentaries by Patiño and Chirro-short and longer form-have worked to make Galician landscape, identity, and ways of seeing visible through dematerialized digital moving images that circulate digitally through the world. The geographic specificity of a film like Lois Patiño's «Noite sem distância» (20I5) works to activate international viewers' consciousness of (remote) Portuguese and Galician landscapes and cultural tropes, even as it has some fun with the technologies and practices that make those landscapes visible onscreen and audible on the soundtrack. Yet in that film we can see how Galician documentary has made productive use of a variety of reflexive visual strategies and audiovisual technologies to tell stories about its people's place in the world, and to make those places perceptible within the audiovisual structures of their moving pictures.

${ }^{6}$ Gómez Viñas begins his description of Galician film history by noting the industry's critical awareness of «its own historical "nothingness"» (2014: 136), and outlines how, from its beginnings, «cinematic expression in Galicia appears to have developed in fits and starts as a succession of births, deaths and rebirths, or even as a blank slate still to be written on» (20I4: I35).

Abriu, 7 (2018): 81-99

ISSN: 2014-8526, e-ISSN: $2014^{-8}-534$ 
Similarly, Patiño's «Fajr» is an enigmatic twelve-minute meditation on landscape and human disconnection. Meditative and lyrical, the film was shot in Morocco in 2016. Its enveloping atmospheric sound of white noise (cars on a highway? Wind through the trees?) accompanies dimly-lit long shots of a desert landscape, where two human figures can be seen, gradually appearing and disappearing as the light value increases and diminishes. Human movement only occurs after the third minute, when the figure in the background walks slowly across a dune. At the five-minute mark, the voice of Mishary Rashid Alafasy can be heard singing «Recitation I».7 The song lasts roughly two minutes. The play of light, shadows, darkness and focus calls into question the realism of mise-en-scène, instead emphasizing the gestural capacities of digital film recording and expressionistic soundtrack. A hooded figure appears, towards the end of the film, in the shallow shore of the sea, and the waves become the dominant acoustic sounds.

Colmeiro has described Patiño's anti-naturalist, hybrid style, and asserts that the director's «films create extraordinary estrangement effects through the repeated use of long and static shots of the Galician coastal scenery, the exaggerated dwarfing of human figures against stunning panoramic images, and the frequency of extreme high-angle shots from humanly impossible observation points» (20I7: 200). These techniques function, especially in his longer form film Costa da morte (2013), as a more complex response to mainstream cinema that aims to create what Patiño calls a «double distance» that aims to create a heightened sense of visual and auditory texture. In all of his films, storytelling is subordinated to meditative visual and auditory structures and onscreen human agency is reduced to a minimalist presence that functions almost exclusively as a marker of physical scale.

The aesthetics of Costa da morte are not dissimilar to Patiño's earlier film «Montaña en sombra» (20I2), a contemplative landscape-driven movie shot in the French Pyrenees and Iceland. ${ }^{8}$ The film opens with the insistent sounds of labored human breathing, which are overlaid on a snowy landscape where distant human figures can be seen walking up a slope. A series of cuts link progressively more distant aerial shots of those humans skiing across the

7 The final title sequence credits Adhan, with voice by Al Afasi (Alafasy).

${ }^{8}$ Gonzalo Enríquez Veloso notes that although Costa da morte evokes a mythical kind of temporality and identity, Patiño's use of the human voice and social space infuse the film with an anthropological aura (2014).

Abriu, 7 (2018): 8I-99

ISSN: 2014-8526, e-ISSN: 20I4-8534 
slopes, with the sound of wind rushing across the microphone. As in Costa da morte, humans are placed into extremely austere physical environments where they appear as expressionistic details within an otherwise uniform natural environment. The visual structures of the black and white «Montaña en sombra» are established by the shadows of ski-lifts, the marks and striations that skiers have left on the mountains, the contours of the mountain and its snow and light and shadow. Thus, the snow becomes a canvas for abstract human expression not unlike a Miró painting.

At the halfway point of «Montaña en sombra», the ambient sound of Ann Deveria's «Embarcadero (Parte 2)», is heard on the soundtrack. Deveria's arrhythmic avant-garde musical composition complements and enhances Patiño's reflection on space and time. In an interview, the director has described «Montaña en sombra» as a condensation of some of his central concerns: «the balance between abstraction and figuration; the pictorial approach achieved through a flat image and spots of black shadow; the work with the immensity of landscape and the insignificance of a human being in it; the creation of a double perception arising between image and sound; the physical effort made in open nature; the search for a poetic image» (Cutler 20I4: I7).

Elsewhere in the interview, Patiño remarks that «the action of time passing leads our consciousness to re-evaluate an image constantly, giving it new meaning. We never see the same image twice from second to second, even if it seems like the shot has not changed» (Cutler 20I4: 18). This is a distillation of his approach to making contemplative cinema. Given his interest in time

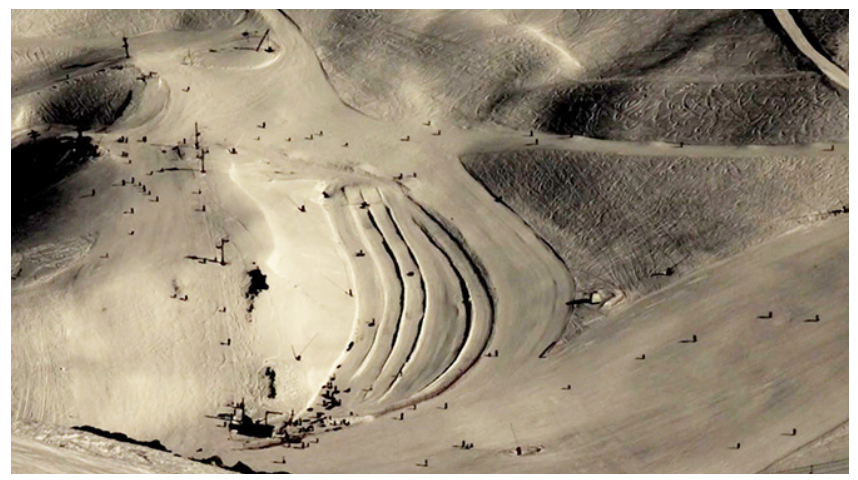

Figure i. «Montaña en sombra» (20I2). Documentary film as abstract-figurative landscape. 


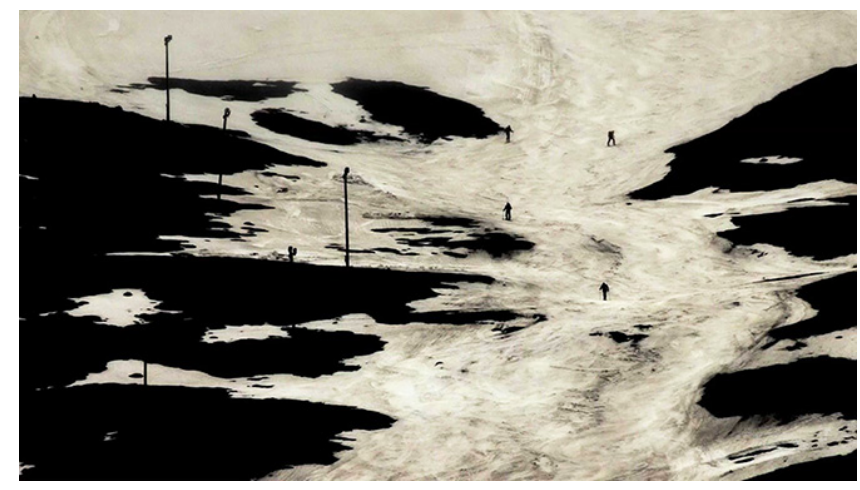

Figure 2. «Montaña en sombra» (20I2). Shadows, snow and human figures.

and temporality, unsurprisingly Patiño cites Henri Bergson's notion of duration as a key inspiration for his work: «an instant of time expanded within our consciousness through the intensity of its experience» (Cutler 20I4: I8). Patiño describes how the tension between internal perception of time and external time can function in a film, and this temporal/reflective approach to representing time and temporality plays a major role in Patiño's conceptual and contemplative cinema. He deploys minimalist editing to achieve «maximum energy» (Cutler 20I4: I8), even if that energy is latent or not immediately visible onscreen. Extremely long takes collapse the time of viewing and the time of filming, extending the cinematic sense of time. Where there are cuts, they tend to be effaced through digital fades or more bespoke methods of blurring the image, sometimes with Vaseline or paint. Patiño also cites the films of Peter Hutton, James Benning and Sharon Lockhart as influences: «their films in particular have helped me understand time as a result of the process of contemplation, with an image's energy developing over the course of the length of a shot» (Cutler 20I4: I8). «Noite sem distância» (20I5), for example, opens with a quotation from Portuguese poet Teixeira de Pascoaes, which refers to landscape and its evocation of «Pressentimentos, figuras, apariçoes». A title identifies that the landscape before the camera is «Galicia». Digitally altered static shots of landscape offer negative colorations. Again with the sound of wind, distant dogs on the soundtrack remind the viewer that time is unfolding, even if the visual structures of the film do not mark action or narrative advancement. Human figures, rather than promoting plot lines or emotional 


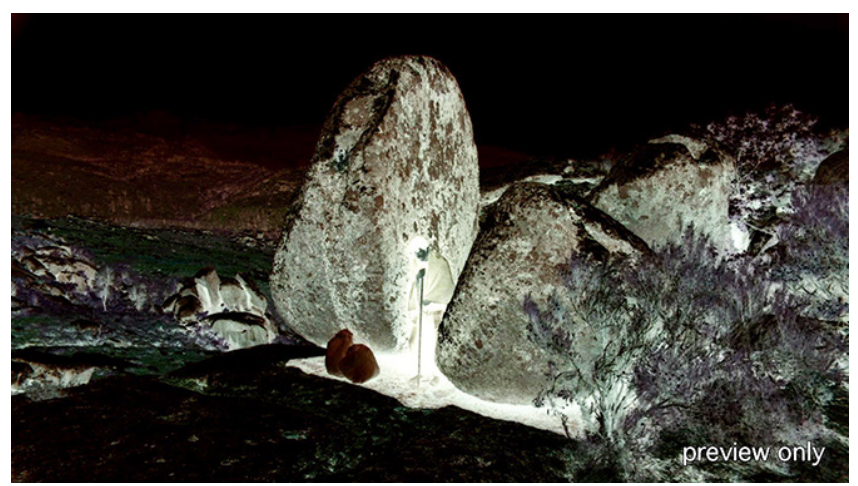

Figure 3. Negative image tableau in «Noite sem distância» (2015).

connections, are arranged expressively onscreen within landscapes that evoke medieval or renaissance tableaux.

«Noite sem distância» is not without a narrative; cryptic dialogue between two unnamed men deals with smuggling and a rendezvous with «os portugueses». There is a visual disjuncture between the details of nighttime meetings_-otherwise the stuff of action movies — and the static posture of the men who do not move at all. Only their clothing is in movement, whipped about by the mountain winds. There is no appreciable difference in the landscape images of Portuguese milieu and Galician ones, although a later title notes that the plot-such as it is - takes place also in Portugal. Other human figures discuss the arrival of the «Gallegos». Again, the entire film is shot with negative light, which transforms the noir conceit (nocturnal meetings, smugglers in the forest, waiting to exchange contraband) into an avant-garde expressionist tableau.

Patiño's «Estratos de la imagen» (2015) explores the intersection of landscape painting and a contemplative, slow cinema. It is comprised of a long take digitally manipulated to shift, over the course of four minutes, from black and white to undulating multiple colors. The imperceptibly shifting image is of a waterfall that begins to flow backwards as a human onscreen observer disappears. Elaborated without cuts, the film is an example of how the director, in his own words, «tries to explore the audiovisual language through combining cinema with painting» (Cutler 20I4: I7). By altering the lens with grease, paint, and filters Patiño distorts the image, transforming digital photography into figurative media. He does the same with «Duración-Paisaje»(2009-I2) and «Montaña en sombra». 
Patiño has mentioned how the animating impulse of his films has always been a way to explore «how history and legends help to create a landscape's atmosphere» (Cutler 20I4: I6). Far removed from any traditional sense of narrative development, personal identity, or even straightforward figurative representation, his works visualize human figures embedded sonically and visually_not socially or politically-within a landscape in a constant state of flux. The director describes his desire to render the «intimacy» and «immensity» of surroundings (Cutler 20I4: I6); this intimacy is most often rendered through acoustic structures that enmesh the spectator within a trance-like aural repetition, while the director's sense of «immensity» is derived from a factor of a scale of incommensurability between human objects and natural environments. In other words, the disjuncture between human form and non-human surroundings might be described as a visual manifestation of what Patiño calls his «search for the sublime» (Cutler 20I4: I7). Chirro and Laxe are similarly interested in making visible these kinds of dislocations of Galician peoples traversing inhospitable but beautiful landscapes, but of the three directors, Patiño offers perhaps the most radical break with a realist representation of space, time, or narrative.

In the second epigraph to this essay, Jesús Díaz points to the popular and technological origins of the documentary form, and how nonfiction film «es un hijo bastardo, su madre no fue la literatura sino las pobres ferias populares; su padre fue el desarrollo tecnológico, no el arte» (I980: 474). More recently Bill Nichols has described how documentary modes have challenged the epistemological modes and positivistic positioning of traditional nonfiction film: «documentary has come to suggest incompleteness and uncertainty, recollection and impression, images of personal worlds and their subjective construction. A shift of epistemological proportions has occurred. What counts as knowledge is not what it used to be» (Nichols I994: I). While documentary has traditionally sought to trigger viewers' epistephilia, contemporary Galician documentary has shifted its focus into a more ontological realm, where being and perception are fused in an extended time of viewing. ${ }^{9}$

In this line, Vivian Sobchack writes, in her essay on the phenomenology of documentary film, that «we must remind ourselves that a "documentary" is

9 Epistephilia is part of «a distinctive form of social engagement» (I99I: I78) that Nichols considers essential to the responsibly made documentary film.

Abriu, 7 (2018): 8I-99

ISSN: 2014-8526, e-ISSN: 20I4-8534 
not a thing, but a subjective relationship to a cinematic object» (I999: 25I). In their radical experimentation with documentary film form, either through abstract contemplative cinema in the Patiño mold, or Chirro's more playful found footage experimentation, both filmmakers work to draw attention to that subjective relationship that is at the center of the documentary film experience. In this regard, both filmmakers embody what Villarmea has called the formal and thematic «juego permanente» that lies at the center of the NCG aesthetic (2015: 214).

What is documentary film? When we view the world through the lens of Patiño and Chirro, that question tends to recede before a more compelling reflection on visual form and the time-image. And what is Galician documentary film? In the hands of its more adventurous practitioners, this question is similarly difficult to answer. Colmeiro describes Chirro's film Vikingland as a «metaphor for Galician diasporic mobility and hybrid cultural identity» (20I7: 203). But Galicia as a place is mostly invisible in that film. Nor does Galicia appear in his more recent 2017 short documentary film «Textil Movie», in which Chirro arranges a series of extreme close-ups of multicolored textiles, drawing nearly microscopic attention to the physical materials supporting global textile industries and labor exploitation. Inspired by the 25 April 2013 factory fire in Bangladesh that claimed more than I,000 lives-mostly of women, including minors - and that injured nearly 2500 , the film draws attention to the imbrication of Spanish capital in global circuits of commerce. The factory supplies global brands with textiles produced in the factory under sweatshop conditions and was one of several that supplied textiles to the Galician-based global textile enterprise Inditex (Zara and Bershka are two of its brands), one of the planet's largest fashion retailers (Agencias 2013). Through a sequence of titles, the film provides an economic context for the series of close-up textile images that follow, which connect physical evidence from the factory fire to identical cloth samples chosen from Western department stores and boutiques. The images are «found footage» taken from police evidence used in the United Nations investigation that followed the fire; the film concludes by drawing attention to how these images improved conditions for some workers, while also shedding light on the plight of international global labor. Fast cheap fashion is a billion-dollar industry that links the planet mostly for ill (Morgan, True Cost). Chirro's short documentary reminds viewers that Galician capital has left its mark on far-flung continents, people, and environments. 
Colmeiro describes what he calls the central tensions in the films of the NCG, «between documentary/fiction, modernity/tradition, urban/rural, and nature/culture» (20I7: I83). Gómez Viñas asserts that the NCG rejects «the notion of clear-cut filmic genres, preferring instead to explore the interstitial spaces between documentary film and fiction» (20I4: I53). Yet, as the ample bibliography on documentary film attests, these tensions have been present in the form from its beginning. ${ }^{10}$ Most theoretical and historical accounts of documentary film begin by acknowledging the porousness and heterogeneity of the genre while attempting to outline some kind of classificatory scheme. ${ }^{\text {I }}$ Pointing principally to Dziga Vertov's A Man with a Movie Camera (1929) and Jean Rouch's A Chronicle of Summer (I96I), Jay Ruby has argued that «it is to the Russians in the I920s and I930s and the French in the 1950s and I960s that we must look for the true origins of documentary reflexivity» (1977: 7), since it was the early cinema's first practitioners that used documentary film to explore the limits of the form itself, as they worked to discover «new possibilities and untried forms» (Nichols I991: 82). ${ }^{12}$ These and other filmmakers' experimentation with cinematic techniques accordingly «blurred boundaries between fiction and non-fiction, documenting reality and experimenting with form, showing and telling, narrative and rhetoric» (Nichols i99ı: 83).

10 Although «the definition of nonfiction, documentary, or even historiography remains highly elusive, and strongly debated» (Nichols 1994: ix-x), in his influential Introduction to Documentary (200I), Bill Nichols outlines six documentary modes of representation «that function something like sub-genres of the documentary film genre itself: poetic, expository, participatory, observational, reflexive, performative» (200I: 99).

"Nichols's earlier book, Representing Reality: Issues and Concepts in Documentary (1991), only distinguishes between four modes: the expository, the observation, the interactive, and the reflexive (1991: 32). In that book he describes two kinds of reflexivity that are not necessarily separate: political and formal (1991: 69-75). Formal reflexivity can operate stylistically, deconstructively, interactively, ironically, or as parody or satire. For his part, Michael Renov puts forward four modes of documentary, which he describes as «modalities of desire, impulsions which fuel documentary discourse». These modalities serve I. to record, reveal or preserve, 2. to persuade or promote, 3. to analyze or interrogate, and 4. to express (1993: 12-36). Corrigan and White outline four rhetorical positions of documentary film: the explorative, the interrogative, the persuasive, and the reflexive or performative (2009: 283-85).

12 As Jesse Lerner notes, «troublesome hybrids» have for a long time «lurked around the edges of documentary film» (2006: 18), from the silent era to the present.

Abriu, 7 (2018): 8I-99

ISSN: 2014-8526, e-ISSN: 20I4-8534 
As the NCG collective describes their work, «A proposta deste proxecto é darlle a volta, transitar do global ao local, e que a atención e o pensamento caia no Novo Cinema Galego, abordando este campo do xeito máis científico posible, e tratando a información con rigorosidade e metodoloxía» (Bragaña 2015). In the end, Galician documentary becomes a way of seeing, of being in the world, of relating to others. In Chirro's Vikingland, Luís Lomba's video diaries are a more localized, culturally specific response to Vertov's Man with a Movie Camera. He is Vertov's direct heir, wielding his camera in the otherwise alienating milieu of the commercial tanker at sea, interviewing the cooks, the navigators, the crew that do their work for months at a time, far from their families and homelands. Lomba's companionable voice can be heard engaging with his fellow travelers as he experiments with the camera and its functions, testing its technological limits. The camera is visible to everyone onscreen, but never to the viewer, who becomes, at the film's end, a voyeur doubly removed from the lives of the onscreen people. The video camera is visible to Lomba's interlocutors, and many of their filmed encounters begin with the question of whether the «little red light is on». I say doubly removed, because we have not come upon Luís Lomba's video tapes on our own. As Isabel Martínez notes, the film reveals an «historia oculta en unos materiales que a primera vista carecían de valor, un archivo personal de cuatro meses de trabajo en un ferry, donde gracias a la "manipulación" de Xurxo Chirro, se realiza un retrato de la emigración gallega en la década de los noventa» (20I2: 268). Thus, in addition to Lomba, there is another invisible organizing consciousness, that of Chirro, who has fabricated this piece of documentary storytelling using the reels of videotape as found objects. ${ }^{13}$ The film becomes, then, a collage reflection on authorship, authenticity, time and technology. It both reveals social reality but also rebels against traditional modes of documentary practice (Martínez 20I2).

There is a fundamental contradiction at the center of Galician documentary in the global era. If, as Nichols notes, «documentary as a concept or practice occupies no fixed territory» (I99I: I2), in the contemporary Galician context this formal fluidity is held in tension against an opposing and somewhat rigid

13 Martínez asserts that one of the most noteworthy aspects of Vikingland is Chirro's respect for the found footage: «Una de las características que más llaman la atención es el respeto por el material, en el proceso de digitalización no se intentó mejorar la señal audiovisual, se procuró preservar la imagen tal y como fue encontrada que junto con la ausencia de postproducción se respetó el formato original» (2012: 269). 
territorial consciousness. On the one hand, as I outlined in the film analyses above, filmmakers have worked to erode the distinctions between modes and styles of documentary practice through their strategic use of techniques whose ultimate goal is to blur the distinction between reality and fiction, showing and telling, mimesis and poiesis. Yet at the same time that they have problematized formal barriers, boundaries, and distinctions, these directors have also drawn special attention to national and regional geographies, cultures, identities, languages, in order to make the Galician cosmovisión visible onscreen.

\section{WORKS CITED}

Agencias (2013). «La tragedia en Bangladesh destapa "los talleres de la miseria"». El Mundo [online] [April 26, 2013] <http:/www.elmundo.es/elmundo/2013/04/25/ internacional $/ 1366885756$.html .

Amago, Samuel (2017). «Reflexivity in Iberian Documentary Film». The Routledge Companion to Iberian Studies. Ed. Javier Muñoz Basols, Manuel Delgado Morales, and Laura Lonsdale. New York \& London: Routledge, 639-65I.

Ambrós, Jordi (2009). «Financiación y difusión: Mercados y festivales de documental». Doc 2r: Panorama del reciente cine documental en España. Eds. Inmaculada Sánchez and Marta Díaz. Girona: Luces de Gálibo, 223-233.

Bragaña, Álex; González, Xurxo; Martínez, Beli; Pagán, Alberte; Primo, Bárbara (2015). «O proxecto». Novo Cinema Galego [online] [7 November 20I7]. <http:// novocinemagalego.info/s.

Cultura Galega (20I4). «Agro e cinema: No ronsel de Cans», 2r May [online] [I9 January 2015] <http://www.culturagalega.org/noticia.php?id=24279>.

Cerdán, Josetxo (2009). «Desplazamiento centrífugo en tres movimientos sobre la geografía del documental español». Doc 2r: Panorama del reciente cine documental en España. Eds. Inmaculada Sánchez and Marta Díaz. Girona: Luces de Gálibo, 67-80.

Cerdán, Josetxo; Weinrichter, Antonio (2008). «D-Generación: A modo de reflexión introductoria». J. Cerdán; A. Weinrichter (ed.). D-Generación. Experiencias subterráneas en la no ficción española. Madrid: Instituto Cervantes, Festival Internacional de Cine de Las Palmas de Gran Canaria, 10-24.

Corrigan, Timothy; White, Patricia (2009). The Film Experience: An Introduction. Boston: Bedford/St. Martin's.

Colmeiro, José (20II). «Imagining Galician Cinema: Utopian Visions?». Kirsty Hooper; Manuel Puga Moruxa (ed.). Contemporary Galician Cultural Studies: Between the Local and the Global. New York: Modern Language Association of America, 202-20.

Abriu, 7 (2018): 8I-99

ISSN: 2014-8526, e-ISSN: 20I4-8534 
Colmeiro, José (2017). Peripheral Visions / Global Sounds. From Galicia to the World. Liverpool: Liverpool University Press.

Cueto, Roberto (2008). «Pero, ¿Existe un cine invisible?». Cahiers du Cinéma España, I4, July-August, 9-Io.

Cutler, Aaron (2014). «Time and Space: Moments with Lois Patiño». Cinemascope, 57, Winter, 15-20.

DíAz, Jesús ([1980] 2003). «Provocaciones sobre cine documental y literatura». Paulo Antonio Paranaguá; José Carlos Avellar (eds.). Cine documental en América Latina. Madrid: Cátedra, 472-76.

Enríguez Veloso, Gonzalo (20I4). «Aproximación a una crítica espacial de Costa da Morte, de Lois Patiño». Ángulo Recto: Revista de estudios sobre la ciudad como espacio plural, 6. I, 97-I10.

Gallego, María; Martínez, Isabel (2012). «La red: una aliada estratégica en el cine de no ficción». Miquel Francés; Josep Gavaldà; Germà Llorca; Àlvar Peris (eds.). El documental en el entorno digital. Barcelona: UOC, 27-37.

García Espinosa, Julio ([1975] 2003). «Una imagen recorre el mundo». Paulo Antonio Paranaguá; José Carlos Avellar (eds.). Cine documental en América Latina. Madrid: Cátedra, 464-65.

Gómez VIÑAs, Xan (20I4). «Cinema in Galicia: Beyond an Interrupted History». Helena Miguélez-Carballeira (ed.). A companion to Galician culture. Woodbridge, Suffolk: Tamesis, I35-56.

Gubern, Román (2009). «Prólogo». Inmaculada Sánchez; Marta Díaz (eds.). Doc 21 : Panorama del reciente cine documental en España. Girona: Luces de Gálibo, 9-ıHjort, Mette; Petrie, Duncan J. (2007). The Cinema of Small Nations. Edinburgh: Edinburgh University Press.

Hooper, Kirsty; Puga Moruxa, Manuel (20II). «Introduction: Galician Geographies». Kirsty Hooper; Manuel Puga Moruxa (eds.). Contemporary Galician Cultural Studies: Between the Local and the Global. New York: Modern Language Association of America, I-I6.

Lerner, Jesse (2006). «Troubling Taxonomies». Alexandra Juasz; Jesse Lerner (eds.). F is for Phony: Fake Documentary and Truth's Undoing. Minneapolis: University of Minnesota Press, 18-35.

Martínez Martínez, Isabel (2012). «Vikingland el cine Rev/belado». Doc On-line, I3, December [online] [2I November 2017] <www.doc.ubi.pt>, 265-274.

Morgan, Andrew (dir.) (2015). True Cost. Untold Creative \& Life Is My Movie Entertainment: U.S. 92 min.

Nichols, Bill (I99I). Representing Reality: Issues and Concepts in Documentary. Bloomington, IN: Indiana University Press.

Nichols, Bill (1994). Blurred Boundaries: Questions of Meaning in Contemporary Culture. Bloomington, IN: Indiana University Press. 
Pérez Pereiro, Marta (20I4-20I5). «Paisaxe na néboa. Unha cartografía do cinema galego recente». Galicia 2I, F, 77-9I.

Pérez Pereiro, Marta; Redondo Neira, Fernando (2013). «Diáspora e experiencia migratoria desde a proposta anovadora dun Novo Cine Galego». Anuario Internacional da Comunicación Lusófona, 54-67.

Redondo Neira, Fernando (20i6). «Los festivales de cine como impulsores del Novo Cinema Galego: Propuestas confluyentes». José Rodríguez Terceño (ed.). La realidad audiovisual hoy: Cine, TV y Red, 71, 329-340.

Redondo Neira, Fernando; González Rodríguez, Xurxo (20I4). «Lo procesual como marca de modernidad en el Novo Cinema Galego». Actas - VI Congreso Internacional Latina de Comunicación Social - VI CILCS - Universidad de La Laguna, I-2I.

Renov, Michael (1993). «Toward a Poetics of Documentary». Michael Renov (ed.). Theorizing Documentary. New York: Routledge, 12-36.

Ruby, Jay (1977). «Reflexivity and the Documentary Film». Journal of the University Film Association, 29.4, 3-1.

Sовснаск, Vivian (1999). «Toward a Phenomenology of Nonfictional Film Experience». Jane M. Gaines; Michael Renov (ed.). Collecting Visible Evidence. Minneapolis: Minnesota University Press, 24I-54.

Villarmea Álvarez, Iván (2015). «Identidades transnacionales en el Novo Cinema Galego». Marta Álvarez; Hanna Hatzmann; Inmaculada Sánchez Alarcón (eds.). No se está quieto: Nuevas formas documentales en el audiovisual hispánico. Madrid: Iberoamericana/Vervuert, 20I-I6. 